\title{
Yeni Toplumsal Hareketler Bağlamında Black Lives Matter (BLM) Örneği
}

\author{
İhsan KONAK* \\ Bitlis Eren Üniversitesi
}

\section{Öz}

Bu çalışma Black Lives Matter (BLM-Siyahların Hayatı Önemlidir) hareketini yeni toplumsal hareketler bağlamında değerlendirmeyi amaçlamaktadır. Öncelikle yeni toplumsal hareketlerin teorik çerçevesi ve geleneksel "eski" toplumsal hareketlere nazaran "yeni" nitelendirmesinin gerekçeleri ortaya konulmaktadır. Ardından Black Lives Matter hareketinin ortaya çıkış ve gelişim sürecine yer verilmektedir. Bu noktada sosyal ağların hareketin gelişimindeki rolü irdelenmektedir. Bir twitter etiketi olarak ortaya çıkan BLM hareketinin diğer siyah özgürlük hareketlerinden farklı olan yönleri, Amerikan kamuoyundaki BLM algısı ve BLM'ın Amerikan kamuoyuna etkisi değerlendirilmektedir. Sanal âlemde sosyal medya platformları aracılığıyla ortaya konulan birlikteliğin Amerikan sokaklarına yansıması ve toplumsal harekete dönüşümü analiz edilmektedir.

\section{Anahtar Kelimeler}

Yeni Toplumsal Hareketler, Black Lives Matter, Sosyal Medya. 


\title{
The Case of Black Lives Matter (BLM) in the Context of New Social Movements
}

\begin{abstract}
This study aims to evaluate the Black Lives Matter (BLM) movement in the context of new social movements. First of all, the theoretical framework of the new social movements and the reasons for the "new" characterization compared to the traditional "old" social movements are put forward. Then, the emergence and development process of the Black Lives Matter movement is covered. At this point, the role of social networks in the development of the movement is examined. The different aspects of the BLM movement, which emerged as a twitter hash tag, from other black freedom movements, the perception of BLM in the American public and the impact of BLM on the American public are evaluated. The reflection of the unity put forward through social media platforms in the virtual world to the American streets and its transformation into social movement are analyzed.
\end{abstract}

\section{Keywords}

New Social Movements, Black Lives Matter, Social Media.

\section{Extended Abstract}

Black Lives Matter (BLM) is a new social movement focused on police violence against blacks that has become widespread in America in recent years. The fact that this violence is not punished by court decisions, regardless of whether it is applied by law enforcement officers or civilians, paved the way for the emergence of the BLM movement. The killing of unarmed blacks in the United States has become an ordinary incident. The phrase Black Lives Matter is a revolt against this situation, emphasizing that black lives should also be valuable. It is a stance against racism, which is thought to be inherent in the American system, and BLM brings racial prejudice to the agenda of the American public. It is argued that this bias targets other marginalized groups as well as blacks.

This contemporary movement, which is expressed in three words, is evaluated in the context of new social movements in this study. In this study, first of all, the relevant literature is explained. By definition, social movements are against the system of thought that dominates societies. It is a collective movement that challenges and conflicts with dominant norms and hierarchies. The traditional social movements that are the product of modernity are class-based (working class) and economy-based movements. The main aim of traditional social movements is to seize or influence authority. Material values are in the foreground. The term "new" was added to these social movements after 1960s. These social movements, which have emerged in the face of the problems caused by different elements of modernity, are conceptualized as new social movements by adding the expression "new". After 1960, it is seen that politics on different issues (postmaterial values such as freedom and identity, alternative democracy models, environment, LGBT rights, etc.) has emerged. As a result of the inadequacy of existing policy understandings and the inability of traditional movements to grasp this "new" situation, the necessity of 
"new" approaches to social movements has arisen. In the American context, BLM is an example of new social movements. BLM, which is thought to have emerged as a result of the struggle against racial discrimination in terms of African Americans, can be evaluated as a contemporary social movement that practices unusual action styles and has a different organizational structure.

The importance of social media (Twitter, YouTube, Instagram, Facebook, blogs, etc.) for BLM, a movement born from a Twitter hashtag, is an undeniable fact. The use of social media by BLM activists has three important functions in organizing efforts: (1) to mobilize internal and external resources; (2) to create cooperation between the groups involved in the BLM movement and other social movements, and (3) to control the narrative of the movement (Mundt etc., 2018: 6). Social media platforms, especially Twitter, facilitate both Black Lives Matter's organization/coordination efforts and its communication with other social movements. Social media platforms offer a more effortless, easily accessible and interactive environment in forming public opinion and public discourse. Social media offers an alternative channel to BLM activists for the movement, which does not take much place in the traditional American media. Alicia Garza, one of the founders of the movement, said in an interview, "We all know that Twitter cannot save us. Twitter can be a tool that connects us and helps us develop strategies on how to build the power we need to transform the world we live in" (Dalton, 2015) and evaluated social media in terms of BLM. Today, social media platforms perform the function of churches and other traditional institutions during the civil rights era for blacks and other marginalized groups in the USA.

This movement started with the shooting of 17-year-old African American Trayvon Martin in Sanford, Florida in 2012 (Clayton, 2018: 450). The acquittal of George Zimmerman, the volunteer neighborhood watchman who murdered Martin, has been a beacon of the BLM movement. After Zimmerman's acquittal, three black female activists Alicia Garza, Patrisse Cullors and Opal Tometi started the movement. The killing of Martin and many other unarmed blacks by civilians or law enforcement officers led to massive protests across the country. Even though the majority of the demonstrations were carried out peacefully, there were also clashes with the security forces. As the BLM strives for a society where blacks are not systematically targeted, the hashtag \#BlackLivesMatter has become a mobilization call for demonstrators. The fact that Trayvon Martin was held responsible for his own death has been a turning point for BLM. Despite the allegations that Trayvon was followed and killed on a racist basis, the release of Zimmerman paved the way for the birth of this movement.

Activists of the movement are active and combative. They employ unconventional courses of action. By disrupting routine life in America BLM activists try to show that this problem cannot be ignored. It is aimed to raise awareness in the American public by slowing down or stopping the trade and routine life in the USA -a country is considered the pioneer of capitalism. Protests have 
been held in all major American cities, and even in places where few African Americans live. It is understood that it has gained popularity beyond expectations. Although they could not find much coverage in the American mainstream media, BLM activists who are organized through social media platforms has managed to influence the public discourse.

There are aspects that make BLM different from other black liberation movements. First, the BLM rejects the singular and male-dominated leadership model adopted by other black liberation movements and emphasizes the participatory democracy. Alternative democracy models are implemented, in which each activist is a leader and has a say in decision-making mechanisms. It is underlined that strong people do not need strong leaders (Demby, 2014). In addition, when evaluated in the context of gender, unlike other black freedom movements, women and other groups in the gender spectrum are more prominent in the black lives matter movement. This movement initiated by three black women, two queers and one Nigerian-American (Tometi, 2015) introduces a new leadership model and brings groups that were previously ignored or not brought to the fore at the center of the movement. Another aspect that sets this movement apart from other black liberation movements is that while pre-BLM movements focus only on blacks (especially those whose biological sex and gender identity are the same), the BLM also highlights other marginalized groups. BLM rejects a male-dominated and hierarchical structure. BLM has a group-oriented leadership and decentralized structure. Although in certain respects it can be seen as a continuation of other black liberation movements, there are points that make BLM unique.

BLM is, however, not free from criticism. There are also some doubts regarding BLM. It is criticized that the demonstrations contain violence. Also, where some see "illegal riots", others participate in "these just riots" (Hooker, 2016: 449). It has also been argued that the BLM movement excludes other lives by specifically underlying black lives. The phrase "All Lives Matter" is used instead of Black Lives Matter.

Despite contributing to the creation of a certain awareness in the American public, it is considered that there are still hesitations about BLM. Although BLM has achieved certain successes, it is debatable whether it can cause a systematic and permanent change. Considering that it will take a long time to rectify the injustice that is thought to have permeated different layers of the American society, it is unclear whether BLM can maintain its existence as a long-term social movement. The acceptance and adoption of the vision by the American public is essential for sustainable social struggle. In this context, it is thought that it is still early to evaluate BLM. Whether BLM will be successful in American politics and what kind of gains it will achieve in the struggle for justice and equality may be a subject of a separate study. 


\section{Giriş}

Yargı sistemindeki ırksal eşitsizlik, Amerika Birleşik Devletleri'nde (ABD) sosyo-politik öneme sahip kronik bir sorun olarak karşımıza çıkmaktadır. Son yıllarda, mahkeme kararlarıyla siyahlara karşı gerçekleşen irksal eşitsizlik, Amerikan kamuoyunun gündemindedir (De Choudhury vd., 2016). Ceza adalet sisteminde yapısal ırkçılığın nasıl işlediğinin bir örneği olan polis şiddetine (Garcia ve Sharif, 2015: 28) ilişkin davalar sonrasında, bugün geçmişte olduğu gibi, ABD'de Afrika kökenli Amerikalıların ve diğer beyaz olmayan grupların orantısız polis şiddetine maruz kaldığı (Weitzer, 2015: 475:480) anlaşılmaktadır. Afrikalı Amerikalılara yönelik polis şiddeti yeni bir vaka olmamasına (Lieberson ve Silverman, 1965: 887-898) karşın, 2012 yllında 17 yaşındaki Trayvon Martin'in öldürülmesinden günümüze, Amerikan polisinin birçok kez silahsız olmalarına karşın siyah erkek ve kadınları öldürmesi, ABD'de de ırksal önyargı konusunu tekrar gündeme getirmiştir. Bu cinayetlerin ardından ortaya çıkan Black Lives Matter (BLM) ("Siyahların Hayatı Önemlidir") hareketi, özellikle Afrikalı Amerikalılar arasında yoğun ilgi ve destek görmektedir ve ırkçllı̆ga karşı verilen önemli bir tepkidir (Leach ve Allen, 2017: 543). Irkçı değer sistemine meydan okuyan (Atkins, 2018: 9) BLM hareketi, silahsız Afrikalı Amerikalının öldürülmesini protesto eden bir toplumsal hareket olarak ortaya çıkmıştır (Clayton, 2018: 448). Beyaz olmayan ten renginin, polis şiddetinin ve yargı kararlarındaki adaletsizliğin başlıca sebebi olduğu düşünülmektedir. BLM hareketi siyahların hayatlarının da değerli olduğu kabulüyle yola çıkar ve diğer marjinalleștirilmiş, toplumun kıyısında duran grupları da temsil etme çabası içerisindedir.

"Siyahların Hayatı Önemlidir" ifadesi, basit olumlu bir cümledir. Onaylama, açıllama veya nitelendirme ihtiyacı, bu ifadenin evrensel olarak doğru veya meşru bir iddia olarak kabul edilmemesinden kaynaklanmaktadır. Aynı zamanda, ters önerme her zaman mevcuttur: siyahların yaşamlarının önemi yoktur (Gafney, 2017: 204). BLM hareketinin bugün ABD'de yaşayan siyahların durumuna ilişkin verdiği mesaj açıktır: devlet, siyah toplumunu sistematik olarak kontrol eden ve yok eden yasaları ve yapıları uygulayarak siyah topluluğuna karşı şiddet uygulamaktadır. BLM, ezilen herkes için özgürlüğü savunur, ancak siyahların yaşamlarının özellikle hedef alındığını kabul etmekle başlar (Clark vd., 2018: 153). BLM hareketi adaletsizliği protesto etmenin ve kamuoyunda farkındalığı arttırmanın bir yolu olarak başladı, sosyal medya örgütlenmesini eski usul sivil itaatsizlikle harmanladı: yürüyüşler, oturma 
eylemleri, polisle çatışmalar. Üç kelimelik bir slogan altında birleşen kasıtlı olarak lidersiz, geçici grup, hızla, ana akım politikacıların görmezden gelmeye çalıştığı yaygın bir harekete dönüştü (Williams, 2015).

Bu çalışma güncel bir hareket olan BLM hareketine odaklanmaktadır. Çalışma BLM'ın doğuşunu, gelişim seyrini ve yapısını, bu süreçte sosyal medyanın rolünü, BLM'ı diğer siyahi hareketlerden farklı kılan yönlerini ve BLM'ın Amerikan toplumu üzerindeki etkisini toplumsal hareketler literatürü çerçevesinde analitik bir incelemeye tabi tutmaktadır. Sanal ortamda oluşan bu birlikteliğin, çevrim içinden nasıl çevrim dışına sirayet ettiği analiz edilmektedir. Sosyal medya platformları üzerinden örgütlenen BLM, siyahların özgürlük ve eşitlik mücadelesinde örgütsel ve eylemsel açıdan "alışılagelmiş" yöntemlerden farklı bir yol izlediği görülmektedir. Bu bağlamda BLM hareketinin incelenmesi, hem Amerikan toplumunda çatışma kaynağı olan bu sorunu anlamamıza hem de literatür çerçevesinde BLM hareketini yorumlamamıza yardımcı olacaktır.

\section{Yeni Toplumsal Hareketler ve BLM}

Genel anlamiyla bir toplumsal hareket, mevcut bir sisteme ve onun değerlerine veya güç ilişkilerine karşı sürekli, bilinçli bir meydan okumada örgütlenmiş bir grup insan olarak anlaşllabilir (Walton ve Smith, 2008: 88). Toplumsal hareketler, tanımları gereği egemen topluma karşıdırlar, diğer bir ifadeyle, toplumun bazı yapılarına, politikalarına veya kültürel normlarına karşı çıkmaktadırlar (Reger, 2014: 43). Bir toplumsal hareket dayanışma temelinde ancak çatışma unsuru/unsurları taşıyan ve içinde bulunduğu sistemin sınırlarını zorlayan kolektif hareket türü olarak tanımlanabilir (Melucci, 1999: 87). Modern toplumsal hareketlerin kökeni 19. yüzyılın bașlarına kadar dayandırılabilir. Hareketin ilk örnekleri işçilerin çalışma koşullarının iyileştirilmesi için mücadele eden emek hareketi, çok uluslu Avrupa imparatorluklarında bağımsızlık mücadelesi veren çeşitli ulusal hareketler ve bilhassa orta Avrupa'da Katoliklerin siyasal hakları için mücadele eden Katolik hareketidir (Heywood, 2013: 364). Modern dönemin başlarında ve henüz global ekonomik ve teknolojik dönüşümlerin yaşanmadığı dönemlerde daha çok sınıf temelli (genellikle işçi sınıfı) ve ekonomik çıkar odaklı ortaya çıkan toplumsal hareketler siyasal iktidarı ele geçirmeyi veya etkilemeyi hedeflemişlerdir (Çopuroğlu ve Çetin, 2010: 72). Eski muadillerine göre 1960 sonrası ortaya çıkan toplumsal hareketler hızlanan sanayileşme, kentleşme, modernleşme ve küreselleşme gibi süreçlerin etkisiyle toplumların değişim ve dönüşümünden etkilenmiştir. Bu doğrultuda sistem karşıtı hareketlerde ciddi bir değişim ve dönüşüm söz konusu olmuştur. 1960'ların öğrenci, yeni sol ve sivil haklar hareketleri; 1970 ve 1980 'lerin LGBT, barış, kadın ve çevre hareketleri; 1990 'ların ve 2000 'lerin küresel adalet hareketi bu bağlamda değerlendirilir (Topal Demiroğlu, 2014: 134-135). Modernitenin farklı unsurlarının sebep olduğu sorunlar karşısında ortaya çlkan bu toplumsal hareketler, "yeni" ibaresi eklenerek "yeni toplumsal hareketler" olarak kavramsallaştırılır. 
Eski ve yeni toplumsal hareketler ayrımı, eski ve yeni siyaset anlayışlarının üzerinden yapıldığında daha da kolaylaşmaktadır. Eski siyasette materyal değerler daha ön plandadır. Bu anlayışa göre temsili demokrasi siyasetin temel mekanizmasıdır ve örgütlenme siyasal partiler ve işçi hareketleri üzerinde gerçekleşmektedir. 1960'lı yıllardan itibaren ortaya çıkan yeni siyaset anlayışında ise özgürlük ve kimlik gibi postmateryal değerler, katılımcı demokrasi fikri, çevre, ifade hürriyeti, LGBT hakları, barış, feminizm gibi konular ön plandadır ve yeni orta sınıf, gençler ve eğitimliler yeni toplumsal hareketlerin taşıyıcılarıdırlar (Topal Demiroğlu, 2014: 136). 1960 sonrasında farklı konular üzerinde siyaset yapma pratiklerinin ortaya çıktığı görülmektedir. Var olan siyasa anlayışlarının yetersiz kalması ve geleneksel hareketlerin bu "yeni" durumu kavrayamaması neticesinde, toplumsal hareketlere ilişkin "yeni" yaklaşımların gerekliliği ortaya çıkmıştır.

Yeni toplumsal hareketler, toplumsal hareketlerin hem makro-tarihsel hem de mikro-tarihsel unsurlarını vurgulayan sosyal teoriye yakın zamanda eklenen bir kavramdır. Makro düzeyde, "yeni" toplumsal hareketler, çağdaş toplumsal hareketlerin yükselişi ile daha geniş ekonomik yapı arasındaki ilişkiye ve bu tür hareketlerde kültürün rolüne odaklanır (Pichardo, 1997: 411). Sosyal çatışmalar ekonomik/endüstriyel sistemden çok kültürel alanda yoğunlaşmaktadır (Melucci, 1999: 88). Mikro düzeyde ise, kimlik ve kişisel davranış konularının sosyal hareketlerle nasıl bağlantılı olduğu ile ilgilenir. "Yeni" toplumsal hareketler, orta sınıf radikalizminin yeni biçimleriyle ilişkili olarak özgül toplumsal hareketler vizyonu sunar. Toplumsal hareketlere ve daha geniş sosyo-politik çevreye, bireylerin sisteme nasıl uyduğuna, sisteme nasıl tepki verdiğine ve sistemi nasıl değiștirdiğine dair bir görüş ortaya koyar (Pichardo, 1997: 411). Yeni toplumsal hareketleri geleneksel toplumsal hareketlerden ayıran başlıca fark, yenilerinin post materyal bir eğilim göstermesi ve toplumsal ilerlemeden çok "hayatın kalitesi"ne odaklanmasıdır (Heywood, 2013: 364). Sınıf çatışması bağlamında hareket eden işçi sınıfi sanayi toplumunun bir ürünü iken, yeni toplumsal hareketler ise sanayi sonrası toplumun (Touraine, 2002: 91-92) veya bilgi toplumunun (Melucci, 1989: 45-46) bir sonucudur. Yeni toplumsal hareketlerin postmateryal çağın bir sonucu olduğu ifade edilir ve sanayi toplumunun işçi sınıfı hareketlerinden farklı olduğu düşünülür (Pichardo, 1997: 412). Eski ve yeni toplumsal hareketlerin farklı tür toplumlarda gelişmiş olduğu görülebilir. Sanayi sonrası toplumlar ekonomik temelde yükselmemektedir; ekonomik, siyasal ve kültürel yapılar giderek daha fazla bir şekilde bütünleşmektedir (Melucci, 1999: 88). Yeni eğitimli sınıfın bir başkaldırısı (Önder, 2008: 597) olarak da izah edilen yeni toplumsal hareketlerin aktörleri kendilerini sosyo-ekonomik bağlamda değerlendirmeye tabi tutmazlar (Cohen, 1995: 667). Yeni toplumsal hareketlerin aktivistleri eğitim seviyesi yüksek, nitelikli işgücünü oluşturan, yüksek statülü mesleklere sahip bireyler, öğrenci, ev kadını, eğitimli işsizler vb. gruplardan oluşmaktadır (Tatar, 2013: 13). Diğer bir farklılık ise eski hareketlerle karşılaştırıldığında yeni toplumsal hareketler ortak bir ideolojik zemine sahiptir ve Yeni Sol'la ilişkilidir: egemen sosyal amaçlara ve siyasetin 
işleyiş biçimine karşı çıkmakta ve kendini gerçekleştirme ve ifade etme gibi liberteryen hedefleri arzulamaktadırlar. Yeni toplumsal hareketler, insanların yaşamlarını değiştirmeye çalışmakta, toplumların genel değişimleri için mücadele ederken insanların kendi yaşamlarını da değiştirebileceğine inanmaktadır (Melucci, 1999: 89). Geleneksel ile yeni toplumsal hareketler arasındaki bir diğer ayrım ise yeni hareketlerin âdemi merkezileşmeye ve karar alma süreçlerine ehemmiyet gösteren örgütsel yapıya sahip olmaları ve yeni siyasal eylem tarzları geliştirmiş olmalarıdır (Heywood, 2013: 365). Offe'nin (1999: 68) vurguladığı üzere, yeni toplumsal hareketler zayıf ve gayri resmi bir örgüt hiyerarşisine sahiptir. Bireysel özerklik yeni toplumsal hareketlerin temel unsurudur. Eski toplumsal hareketlerin dikey hiyerarşik yapısına karşın yeni toplumsal hareketler yatay örgütlenmeyi ve demokratik örgütsel yapıyı benimser. Yeni toplumsal hareketler egemen topluma ve bu toplumda işleyen siyasal politikalara, yapılara ve süreçlere karşı çıkar. Eylemler, anlatılar ve protestolar yoluyla sosyal, kültürel ve politik değişim ve dönüşümleri hedefler.

Tablo 1. Eski ve yeni toplumsal hareketler.

\begin{tabular}{|c|c|c|}
\hline & $\begin{array}{l}\text { ESKI TOPLUMSAL } \\
\text { HAREKETLER }\end{array}$ & $\begin{array}{l}\text { YENI TOPLUMSAL } \\
\text { HAREKETLER }\end{array}$ \\
\hline Katılımcıların profili & $\begin{array}{l}\text { Alt tabaka Sinıf eksenli, } \\
\text { aynılıkların öne çıktığı } \\
\text { çoşkulu ve kalabalık } \\
\text { topluluklar Eğitim seviyesi } \\
\text { düşük bireyler Niteliksiz } \\
\text { işgücü ve işsizler }\end{array}$ & $\begin{array}{l}\text { Orta sınıf Farklılıklarını } \\
\text { vurgulayan gruplarEğitim } \\
\text { seviyesi yüksek bireyler } \\
\text { Nitelikli işgücü, yüksek } \\
\text { statülü meslek grupları, } \\
\text { öğrenciler, kadınlar, eğitimli } \\
\text { ișsizler }\end{array}$ \\
\hline $\begin{array}{l}\text { Örgütlenme yapısı ve } \\
\text { esasları }\end{array}$ & $\begin{array}{l}\text { Resmi, dikey hiyerarşi, } \\
\text { karizmatik otorite/lider } \\
\text { temelli Mekân paylaşımı } \\
\text { Ulusal ve yerel ölçekli }\end{array}$ & $\begin{array}{l}\text { Yatay örgütlenme, özerk } \\
\text { ve adem-i merkezi yapı } \\
\text { Demokratik yapı ve } \\
\text { lidersizlik Bireysel karar } \\
\text { alma mekanizması Sosyal } \\
\text { alan kullanımı ve mekânda } \\
\text { birliktelik Küresel ve yerel } \\
\text { ölçekli }\end{array}$ \\
\hline Değerler & $\begin{array}{l}\text { Materyalist öncelikler, } \\
\text { ekonomik çıarlar, toplumsal } \\
\text { sinıf, milli hassasiyetler }\end{array}$ & $\begin{array}{l}\text { Post materyalist öncelikler } \\
\text { ve farklı olma hakkı Etnisite, } \\
\text { kimlik, din ve dini yorumlar, } \\
\text { cinsel tercihler, çevre, savaş ve } \\
\text { nükleer silah karşıtlığı, barıș, } \\
\text { yoksullukla mücadele }\end{array}$ \\
\hline Duygu & Ezilmişlik, sömürülme & $\begin{array}{l}\text { Ötekileștirilmişlik, } \\
\text { dışlanmışlık ve ihmal }\end{array}$ \\
\hline Kullanılan araçlar & Geleneksel medya araçları & Sosyal ağlar, İnternet \\
\hline Hedef & $\begin{array}{l}\text { Devlet ve iktidar } \\
\text { Ekonomik çıkarlar ve sosyal } \\
\text { haklar }\end{array}$ & $\begin{array}{l}\text { Hak, özgürlük, eşitlik Kültürel } \\
\text { haklar, kimlik, tanınma } \\
\text { Hayatın kalitesine ilişkin } \\
\text { sorunların çözümü }\end{array}$ \\
\hline
\end{tabular}


ABD bağlamında Siyahların Hayatı Önemlidir hareketi yeni toplumsal hareketlere örnek olarak gösterilebilir. ABD’de Afrikalı Amerikalılar arasında süregelen eșitlik mücadelesinin (Clayton, 2018: 449) bir sonucu olarak ortaya çıktığı düşünülen BLM, yeni siyasal eylem tarzları uygulayan ve farklı örgütsel yapısı olan çağdaş bir toplumsal hareket olarak değerlendirilebilir. Amerikan siyasal sistemi normalde yeni ortaya çıkan rakiplerin siyasi arenaya tam olarak girmesini engellemek için çalışır. Bu tür gruplar sadece sistemin normal işleyişinin bozulmasıyla veya meydan okuyan grupların siyasi çatışmayı sürdürmek için gayri meşru yollara başvurarak oyunun kurallarını ihlal etmeye istekli olduklarını göstererek kazanır (Gamson, 1968: 18). BLM'ın bu tarzdan bir mücadele örneği göstermeye çalıştığı görülebilir. Diğer siyah özgürlük hareketlerinden farklı olarak genel kabul gören eylem tarzları yerine "kural dışı" şekilde hareket ettiği söylenebilir.

\section{BLM'ın Gelişiminde Sosyal Medyanın Rolü}

Yeni bir toplumsal hareket olarak Siyahların Hayatı Önemlidir hareketi, İspanya'daki Indignados, ABD'deki Occupy (İşgal Et) Hareketi ve hatta Arap Baharı gibi hareketlerle yakından ilişkilidir (De Choudhury vd., 2016). Çoğu çağdaş Batılı toplumsal hareket gibi, BLM hareketi de çevrimiçi medyayı yoğun bir şekilde kullanmaktadır (Freelon vd., 2016: 7). BLM aktivistleri tarafından sosyal medyanın kullanılmasının, örgütlenme çabalarında üç önemli işlevi vardır: (1) iç ve dış kaynakları harekete geçirmek, (2) BLM hareketine dahil olan gruplar ve diğer toplumsal hareketler arasında işbirliği oluşturmak ve (3) hareketin anlatısını kontrol etmek (Mundt vd., 2018: 6). Yaygınlığı ve benimsenmesi nedeniyle sosyal medya, özellikle Twitter, bu aktivist harekete temel altyapıyı sağlamaktadır (De Choudhury vd., 2016). BLM, destekçileriyle yerel yürüyüşlerin gerçek zamanlı durumları hakkında iletişim kurmak ve onları organize etmek için sosyal adalet forumu olarak sosyal medyayı (ör. Twitter, YouTube, Instagram, Facebook, bloglar vb.) kullanmaktadır (Carney, 2016). Sosyal medyanın, özellikle Twitter'ın, hem BLM'ın hem de diğer toplumsal hareketlerin organize olmasında önemli bir işlev gördüğü anlaşılmaktadır. Sosyal medyanın hem hareketlerin mesajlarını kamuoyuna iletmesinde hem de kendi içinde örgütlenme/koordinasyon çabalarında kolaylık sağladığı görülmektedir.

Sosyal medya, kamusal alana evrensel erişim sorununu çözmekten uzak olsa da, aksi takdirde kamusal alana katılamayacak birçok kişiye yeni bir erişim biçimi sağladığı muhakkaktır. Habermas (1991: 102), kamuoyunun bilgilendirilmiş olanlardan kaynaklandığını ve alt sınıfların, hayatta kalmak için en acil ihtiyaçlarının ötesinde herhangi bir şeyle ilgilenmek için hem boş zamana hem de firsata sahip olmamaları nedeniyle kamuoyuna/kamusal söyleme katıl(a)madıklarını savunur. Teknolojik yenilikler ve cep telefonlarının artan yaygınlığı sayesinde ABD'de çoğu genç, neredeyse her yerde, mütemadiyen kamusal medyada söylemlere erişebilir. Irk hakkında ulusal ve uluslar ötesi 
diyaloglara ekstra zaman ayırmak yerine, internete erişimin artması ve bireylerin cep telefonuyla sosyal medyadaki söylemleri okuyup bunlara katkıda bulunabilmesi ve gençlerin kamusal alana katılımı gündelik bir faaliyet olarak karşımıza çıkar. Kamusal alan evrensel olarak erişilebilir olmasa da, sosyal medyanın yükselişi gençler için ulusal söyleme erişimi artırıyor gibi görünüyor (Carney, 2016: 184). Böylelikle gençler sosyal medya aracılığıyla kamusal alana ve söylemlere rahatça ulaşabilir ve fikir beyan ederek kamuoyunun/ kamusal söylemlerin oluşmasına katkıda bulunabilirler.

Sosyal medya, başlangıçta ana akım medya erişiminden yoksun bir hareket için çok önemli bir alternatif platform sağlar. Irkçılığın Amerikan kültürüne içkin olduğuna ve yasalar ve idari yaptırımlar yoluyla kurumsallaştığına inanan BLM hareketinin kurucuları (Clark vd., 2018: 156), kaygılarını ilk başta sosyal medya aracılığıyla kolluk kuvvetleri tarafından siyah hayatların yok edilmesi (örneğin öldürülmesi) karşısında adalet talep eden \#BlackLivesMatter etiketini kullanarak dile getirdiler (Jones-Eversley vd., 2017: 316). Kamusal protesto ve sivil itaatsizlikle birleștiğinde, sosyal medya platformları \#BlackLivesMatter için güçlü araçlar haline geldi ve hareketin kimliğinin bir parçası oldu (Linscott, 2017: 116). “\#BlackLivesMatter” etiketi, Amerika genelinde bir toplanma çı̆̆lı̆̆ı haline geldi. Sosyal medyayı kullanarak genç aktivistler, protestocuları vakit kaybetmeden örgütleyip harekete geçirebildiler (Clayton, 2018: 452). Facebook, Twitter, Instagram, YouTube ve benzer sosyal medya platformları, BML hareketinin kendi içerisindeki iletişimi, yayılımı ve organizasyonunda etkili olmaktadır. Bu, kısmen sosyal medya teknolojilerinin nesilsel popülaritesinin bir sonucudur, ancak aynı zamanda sosyal medya içeriğinin oluşturulma ve yayılma hızına karşı TV, radyo ve süreli yayınlar gibi eski medyanın görece yavaşlığını yansıtır. Genellikle hareketin ismine eşlik eden etiket, hem \#BlackLivesMatter'ın sosyal medya vurgusunun bir göstergesidir hem de içeriğe köprü oluşturmanın ve viral tarzda yayılmasına yardımcı olmanın pratik bir yoludur. Böylece, twitter etiketleri haberleri yayar ve anlık olayları duyurur. Siyah kurbanların isimleri (örneğin, Michael Brown, Tamir Rice veya Sandra Bland) etiket olarak kullanıldığında, haber öyküleri ve olaylara verilen kişisel tepkiler ile olaylar arasında bağlantı kurulur. Bu şekilde ölen kişiler, trajedik bir şekilde de olsa tekrardan hatırlanır. Etiket olarak kurbanların isimlerin kullanılması, geleneksel medyanın sıklıkla kaçındığı şekillerde trajedilerin anımsanmasını ve farkındalık oluşmasını sağlar (Linscott, 2017: 115). Bu bağlamda, sosyal medya BLM için olmazsa olmaz bir unsur olmasa bile önemli, işlevsel bir unsurdur. Hem Amerikan kamuoyunun bilgilendirilmesi ve şekillendirilmesinde hem de organizasyonel açıdan hareket için kilit bir araçtır. Hareketinin kurucularından Alicia Garza da bir röportajında "Hepimiz, Twitter'ın bizi kurtaramayacağına biliyoruz. Twitter, bizi birbirine bağlayan ve içinde yaşadığımız dünyayı dönüştürmek için ihtiyaç duyduğumuz gücü nasıl inşa edeceğimiz konusunda stratejiler oluşturmamıza yardımcı olan bir araç olabilir" (Dalton, 2015) diyerek bu durumu 
ifade etmektedir. Garza, hareketin diğer kurucuları ve BLM aktivistleri, gerçek bir toplumsal değişim ve dönüşüm için sadece sosyal medya platformlarının ve twitter etiketlerinin yeterli olmayacağının farkındadırlar.

Twitter tarihinde "BlackLivesMatter" ve "Ferguson", sosyal bir amaca atıfta bulunan ve en çok kullanılan etiketler arasında yer almaktadır. Twitter'ın 10. yıldönümü olan Mart 2016 itibarıyla \#BlackLivesMatter etiketi 12 milyondan fazla kez kullanılmıştır ve sosyal bir amaçla ilgili en çok kullanılan üçüncü etiket olmuştur. Listenin başında ise Twitter tarihinde sosyal bir amacı destekleyen en çok kullanılan etiket olan \#ferguson bulunmaktadır ve \#ferguson ilgili 27 milyondan fazla tweet atılmıştır (Lowery, 2017). \#BlackLivesMatter ve \#ferguson etiketlerine ilişkin veriler geleneksel medyada yer bul(a)mayan bir hareket açısından sosyal medya platformlarının önemini ortaya koymaktadır. Sosyal medyanın kamuoyu oluşturma hususunda daha zahmetsiz, kolay erişilebilir ve interaktif bir ortam sunduğu düşünülmektedir.

Bir twitter etiketinden doğan Siyahların Hayatı Önemlidir hareketi (Rickford, 2016: 34), yürüyüşler ve açık hava mitinglerinden çok sosyal medya tarafından yönlendiriliyor ve sosyal medyayı aktif bir şekilde kullanıyor. Twitter, beyaz olmayan gençlerin öncülüğünü yaptığı bir harekete kendilerini ifade etmek için önemli bir platform sunmaktadır. Twitter kullanıcılarının Trayvon Martin, Eric Garner ve Michael Brown'ın hikâyelerini gün yüzüne çıkarması ve yayması tesadüfi değildir (Demby, 2014). \#BlackLivesMatter hareketinden birçok twitter etiketi ortaya çıkmıştır, örneğin \#BlackGirlMagic ve \#BlackGirlsRock, siyah kadınların ve kızların hayatlarını sıklıkla görmezden gelen bir dünyada onların yaşamlarını gözler önüne sermektedir. Siyah aktivistler sosyal medyayı yeniden kodluyor ve çehresini değiștiriyor (Greene-Hayes ve Joy, 2017: 70). Sosyal medyayı etkin bir şekilde kullanan aktivistler, sanal dünyanın "siyah" dostu olmasını hedeflemektedir. Geleneksel medyada fazla yer al(a)mayanların sosyal ağları kendi hedefleri doğrultusunda şekillendirdiği anlaşılmaktadır. Özellikle Twitter geleneksel iletişim araçları karşısında BLM aktivistlerine alternatif bir mecra sunmaktadır. Böylelikle ABD'de siyahlar ve diğer marjinalleştirilen kesimler açısından sivil haklar döneminde kiliselerin ve diğer geleneksel siyah kurumların gördüğü işlevi günümüzde sosyal medya platformları görmektedir.

\section{BLM'ın Gelişim Seyri ve Yapısı}

Siyahların Hayatı Önemlidir hareketi, 2012 yılında Florida, Sanford'da 17 yaşındaki Afrikalı Amerikalı Trayvon Martin'in vurulmasıyla başladı (Clayton, 2018: 450). Görünüșe göre Martin'in bir tehdit olduğunu ve yanlış mahallede olduğunu düşünen beyaz, gönüllü mahalle bekçisi George Zimmerman tarafindan takip edildi. Zimmerman'a 911 konuşmasında Martin'i takip etmemesi söylenmesine karşın yine de onunla yüzleşti ve Martin silahsız olarak kendini savunduğunda Zimmerman onu vurup öldürdü. Zimmerman daha sonra 
tutuklandı ancak bir yıl sonra savunmasında "kendisini tehdit altında hissettiğini" savundu (Griffin, 2015: 44).

BLM hareketi Zimmerman'ın beraat etmesiyle başladı. Üç siyah kadın aktivist Alicia Garza, Patrisse Cullors ve Opal Tometi, daha sonra pek çok beyaz olmayan genç de dâhil olmak üzere pek çok kişiyi ülke çapında sosyal adalet aktivizmine teşvik eden hareketi başlattı (Carney, 2016: 181). "Siyahların Hayatı Önemlidir" ifadesi, başlangıçta "Hayatlarımız önemlidir" olarak ifade edildi (Atkins, 2018: 1). Temmuz 2013'te Zimmerman'ın ikinci derece cinayetten suçsuz bulunması ve cinayet suçlamasından beraat etmesi Alicia Garza'yı derinden etkiledi. Ertesi gün Facebook'a giriș yaptı ve kendi sayfasında "Siyah insanlar, sizi seviyorum. Bizleri seviyorum. Hayatlarımız önemlidir" notu ile biten bir mesaj yayınladı (Day, 2015). Garza'nın yaklaşık 500 km uzaktaki yakın arkadaşı Patrisse Cullors o gece yazıyı okudu ve arkadaşlarıyla internette paylaştı. Her seferinde tekrardan yayınladığında \#BlackLivesMatter etiketini kullandı (Cobb, 2016). Garza ve Cullors etiketi duyurmaya başladılar ve Garza'nın tanıdığı göçmen hakları aktivisti olan Opal Tometi, Facebook ve Twitter'ı kullanarak bir sosyal medya platformu oluşturmayı kabul etti. Ancak BLM, Darren Wilson adlı beyaz bir polis memurunun Ağustos 2014'te Missouri, Ferguson'da 18 yaşındaki Afrikalı Amerikalı Michael Brown'ı vurup öldürene kadar ivme kazanmadı (Cobb, 2016).

2014 yılında kamuoyunda geniş yer tutan siyah erkeklerin emniyet güçleri tarafindan öldürülmesi, hareketin yaygınlaşmasına neden oldu. Ölenler arasında 43 yaşındaki Eric Garner, 12 yaşındaki Tamir Rice, 22 yaşındaki John Crawford ve cesedi Missouri, Ferguson sokaklarında saatlerce kalan 18 yaşındaki Michael Brown da bulunmaktadır. Brown'ın ölümü, Ferguson'da ve ülke çapında büyük protestolara neden oldu ve böylece Brown'ın ölümü hareketin sembolü oldu. BLM hareketi sosyal medyanın yardımıyla New York, Boston, Los Angeles, Philadelphia, Miami, Detroit, Houston, San Francisco ve Portland da dâhil olmak üzere ABD'nin dört bir yanında 18'den fazla şehirde 500'den fazla kişi için Ferguson'a Özgürlük Yürüyüşü (Sivil Haklar Hareketi sırasındaki 1961 Özgürlük Yürüyüşlerini anımsatan) düzenledi (Cobb, 2016). Yüzlerce kişi “Siyahların Hayatı Önemlidir!” yazan tişörtler giydi ve pankartlar taşıdı. Bu ifade, genellikle Afrikalı Amerikalılar için yoksulluk, hapis, standartların altında eğitim, yüksek bebek ölümleri ve kötü sağlık koşullarına neden olan adaletsizlikleri (köle gemilerinden günümüze) çağrıștırmaktadır (Young III, 2015: 210). Kolluk kuvvetleri gözetiminde işlenen ve mazur görülen silahsız siyah erkek, kadın ve gençlerin öldürülmesine tepki olarak yapılan büyük ölçekli protestolar, "Siyahların Hayatı Önemlidir"i tanıdık bir ifade haline getirdi (Atkins, 2018: 1). Bu bağlamda BLM siyahların sistematik olarak hedef alınmadığı bir toplum için çabalarken, \#BlackLivesMatter etiketi göstericiler için adeta bir seferberlik çağrısı haline geldi. Trayvon Martin'in âdete kendi ölümünden sorumlu tutulmasının BLM için bir dönüm noktası olduğu düşünülebilir. Trayvon'ın ırkçı temelde siyah olduğu için takip edildiği 
ve öldürüldüğü iddialarına karşın Zimmerman'ın beraat etmesi, bu hareketin doğmasına zemin hazırlamıștır.

Siyahların yaşamlarının önemli olduğunu vurgulayarak protestocular ve sosyal medya aktivistleri siyah olmayanların hayatlarını geçersiz kılmaya çalışmadılar, aksine ABD’de siyahların günlük olarak karşılaștıkları sistemik şiddet ve baskıya anlık olarak dikkat çekmeye çalışmışlardır (Carney, 2016: 194). Protestocular, Ferguson'da işaret ve pankartlar taşıma ve siyahların hayatı önemlidir sloganları atma şeklinde barışçıl yürüyüşler başlatırken, yerel ve eyalet polis departmanlarının silahlı müdahalesiyle karşılaşmışlardır. Polis ve protestocular çatışınca protestoların bir kısmı şiddetlenmiştir. Bunun üzerine vali ulusal muhafızları çağırmış ve olağanüstü hal ilan etmiştir (Clayton, 2018: 455). Tarihsel bir gerçeklik olarak Amerikan tarihi bağlamında var olan siyahlara karşı şiddet (Aymer, 2016: 367) tekrar gün yüzüne çıkmıştır. Kolluk kuvvetlerinin barışçıl gösterilere orantısız güç kullanarak müdahalesinin, olayların daha da büyümesine ve şiddetlenmesine sebep olduğu düşünülebilir. Emniyet güçlerinin silahsız siyahlara karşı müdahaleleri ve bazı müdahalelerinin ölümle sonuçlanması, BLM hareketinin polis şiddetine odaklanmasina neden olmuştur.

"I can't breathe" (Nefes Alamıyorum) aynı şekilde BLM'ın polis şiddetini çarpıcı bir şekilde ortaya koyan bir slogandır. 2014 yılında Afrikalı Amerikalı Eric Garner, New York polis departmanında görev yapan Daniel Pantaleo tarafından gözaltına alınırken hayatını kaybetmiştir. Garner, Panteleo'yu “nefes alamıyorum" diyerek defalarca uyarmış ancak dikkate alınmamıștır. Göğsüne bastırılması ve yüzüstü yatırılması nedeniyle boğularak hayatını kaybettiği düşünülen Garner'ın ardından polis memuru hakkındaki suçlamalar düşürülmüştür (Carrega, 2019). Aynı şekilde Javier Amber (Plohetski, 2020), Manuel Ellis (Johnson, 2021), Elijah McClain (Levenson ve Chan, 2021) ve George Floyd (Singh, 2020) gibi sayısız Afrikalı Amerikalı kolluk kuvvetleri ile karşılaşmalarında aynı ifadeyi kullanmak zorunda kalmışlardır. "Nefes Alamıyorum!" cümlesi, polis şiddetine karşı BLM eylemlerinde kullanılan yaygın bir slogan haline gelmiştir. Silahsız siyahların emniyet güçleri tarafından nefessiz bırakılarak öldürülmesi, Amerika genelinde protesto gösterilerine sebebiyet vermiştir.

2015 yılında, Baltimore'da, Freddie Gray'in gözaltındayken aldığı yaralar nedeniyle ölümünden sonra benzer protestolar patlak verdi. Yine polis ve protestocular arasında çatışma çıkmış, olağanüstü hal ilan edildi ve düzeni sağlamak için ulusal muhafızlar çağrıldı. ABD’nin dört bir yanında silahsız siyah erkek ve kadınlar polis memurları tarafından öldürülmeye devam ettikçe, BLM Afrikalı Amerikalılara yönelik polis şiddetine tepki olarak protestolar düzenlemek için sosyal medyayı, özellikle Twitter ve Facebook'u, kullanmaya başladı. Böylelikle BLM, toplumsal bir harekete dönüştü. \#BlackLivesMatter ifadesi tişörtlerde, kupalarda ve rozetlerde yer almaya başladı; Law and 
Order ve Empire gibi televizyon dizilerine konu oldu (Clayton, 2018: 455). Temmuz 2016'da NBA (Ulusal Basketbol Birliği) oyuncuları Carmelo Anthony, Chris Paul, Dwyane Wade ve LeBron James Amerika'da siyahlara yönelik polis şiddetine son verilmesi çağrısında bulundukları bir BLM konuşmasıyla Espy Ödüllerinin açılışını yaptı (Dessem, 2016). 2014 yılından beri ABD’nin dört bir yanındaki üniversite kampüslerinde düzenlenen öğrenci gösterileri, yürüyüşler ve protestolarda "Siyahların Hayatı Önemlidir" sloganları atıldı (Clayton, 2018: 455). Bu bağlamda Amerikan toplumunun farklı katmanlarında Siyahların Hayatı Önemlidir hareketine ilişkin farkındalığın, desteğin ve katılımın olduğu görülebilir. BLM ABD'de siyahlar açısından süregelen eşitlik ve adalet mücadelesinin devamı olarak değerlendirilebilir. Sosyal medya üzerinden örgütlenen bu hareket "viral" olmaya adaydır. BLM'ın varlığını sosyal medya platformlarından Amerikan toplumuna ve sokaklarına taşıdığı görülebilir.

Günümüzün Ferguson'dan ilham alan BLM hareketinin gücü birkaç yolla ölçülebilir. Birincisi, hareket başlangıcından beri aktif ve mücadelecidir. Hareketin sokak protestoları ve sosyal medyadaki en popüler sloganlarından biri “Onu kapatın!"dır ve retorik bir slogan olmanın ötesine geçmiştir. Onlarca şehirde aktivistler trafiği aksatmak için otoyollarda yürürken; trenleri durdurmak için demiryolu rayları boyunca kol kola girerken; şehir merkezlerinde kavşaklarda otururken; spor müsabakalarının başlamalarını geciktirirken ve alışveriş merkezlerinin, büyük perakende mağazalarının, polis merkezlerinin ve belediye binalarını geçici olarak işgal ederken, sloganın gerçek hayatta da karşılık bulmasını sağlamışlardır. Aktivistler, siyah karşıtı ırkçılığın işe gidip gelmede, ticari hayatta ve Amerikan toplumunun günlük işleyişinin diğer evrelerinde aksamalar yoluyla yüzleşilmesi gereken sistemik bir sorun olduğu sonucuna vardılar (Peterson-Smith, 2015). Aralık 2014 ve Aralık 2015'te Minnesota, Bloomington'daki Mall of America'da düzenlenen BLM protestolarında yerel ve ulusal aktivistler sırasıyla polis vahşeti ve silahsız genç bir siyah olan Jamar Clark'ın öldürülmesini protesto etmek için toplandı. Mall of America, sermayenin Amerikan kültüründeki önceliğinin simgesidir. Devasa bir özel alışveriș merkezidir ve Aralık ayında yılın en yoğun alışveriş sezonu için zengin dekorasyonlarla süslenir. Hareket, bu tür bir tüketim aşırılığına karşı binlerce beden yerleştirerek, siyah yaşamın hem sermaye hem de siyah karşıtı şiddete göre öncelikli olması gerektiğine dair net bir mesaj verdi (Linscott, 2017: 109). Mall of America'da BLM protestocuları siyah topluluğuna karşı olağan askerileştirilmiş aşırı tepkiyle karşılandı: devasa bir polis varlığı, bomba arama köpekleri, zırhlı polisler, kelepçeler, acil durum önlemleri, barikatlı kapılar, tutuklamalar, tartaklamalar... \#BlackLivesMatter'ın taktikleri geçici olarak sermaye akışını kesintiye uğratırken ve siyah hayatı ticaretin önüne koyarken, siyah hayatların kendilerinin de "sorun" olduğu ve devlet iktidarı ve polis terörünün bu "soruna" yanıt olduğu (Linscott, 2017: 111113) düşünülmektedir. BLM aktivistleri radikal bir şekilde Amerikan günlük 
yaşamını sekteye uğratırken siyahlara yönelik ırksal adaletsizliğin görmezden gelinemeyeceğini ortaya koymaya çalıșmaktadırlar. Kapitalizmin öncüsü sayılan ABD'de ticaretin ve rutin hayatın yavaşlatılması veya durdurulması yoluyla Amerikan kamuoyunda farkındalığın sağlanması hedeflenmektedir.

Hareketin gücünün bir diğer göstergesi, yaygınlığıdır. ABD’nin tüm büyük şehirlerinde BLM protestoları gerçekleșmiştir. Ancak, 7 Ocak'ta Westford, Massachusetts'te 11 yaşındaki beyaz bir kızın düzenlediği dayanışma mitingi gibi, az sayıda siyah sakinin bulunduğu kasabalarda da protestolar olmuştur. Aslında, siyah aktivistler Ferguson'da isyan ettiklerinden beri hareketin itici gücü olsalar da, büyük şehirlerdeki protestolar karakter olarak çok ırklıdır. ABD'nin dört bir yanındaki lise, ortaokul ve hatta ilkokul öğrencileri protestolar başlatmış ve gösterilere katılmışlardır. Üniversite kampüslerinde protestolar düzenlenmiştir ve hatta tıp öğrencileri tarafından özel olarak düzenlenen bir eylem gerçekleştirilmiştir. "Siyahların Hayatı için Beyaz Önlükler" protestolarına ülke çapında yetmişten fazla tıp fakültesi katılmıştır (Peterson-Smith, 2015).

BLM'ın aktivizmi, ırkçılığa ve polis vahşetine ve genel olarak sistematik baskıya (Parker, 2016) karşı eşi görülmemiş bir kitle hareketini (Chatelain ve Asoka, 2015) ortaya çıkardı. Başlangıçta sadece protesto hareketlerinin radarında geçici, önemsiz bir nokta olarak görülen BLM (Sidner ve Simon, 2015), Birleşik Devletler'de düzenlenen protesto gösterileriyle birçok akademisyenin beklentilerini aştı ve yapılan bir Pew anketine göre ülke çapında yaygın bir farkındalık kazandı (Horowitz ve Livingston, 2016). Hareketin gerçek başarısı ise radikal söylemi popülerleştirmesinde ve canlı bir demokratik katılım modeli sağlamasında yatmaktadır (Rickford, 2015: 35). Yirmi birinci yüzyıla ait bir olgu olan ve genellikle bir etiket ile yazılan BLM, irk ve polis şiddeti üzerine medyatik ve ulusal söylemlerin oluşturulması, ülke çapında parlamento binalarından konfederasyon bayraklarının kaldırılması ve bir dizi yüksek profilli protestolar ve eylemler dâhil olmak üzere bazı önemli siyasi ve kültürel başarılar elde etmişlerdir. Tüm bunlar, ana akım basının, politikacıların ve genel olarak Amerikan kamuoyunun derin kararsızlığına rağmen gerçekleşmiştir (Linscott, 2017: 107). Hareketin beklentilerin ötesinde popülarite kazandığı görülmektedir. Bu noktada Amerikan ana akımında yer bulamamalarına karşın sosyal medya platformları üzerinden örgütlenen BLM aktivistleri, Amerikan kamusal söylemini şekillendirmeyi başarmış gözükmektedirler.

2016 yılında yapılan bir Pew anketine göre Amerikalıların BLM hakkındaki görüşlerine ilişkin bazı temel bulgular şunlardır: (1) Yaklaşık her on Amerikalıdan dördü, Siyahların Hayatı Önemlidir hareketini destekliyor; (2) Beyazlar arasında Demokratlar ve 30 yaşın altındakiler BLM'ı destekliyor; (3) BLM'a aşina olan Amerikalıların yaklaşık üçte biri, hareketin hedeflerini anlamadıklarını söylüyor; (4) Siyahların BLM'ın uzun vadede etkili olacağını söylemesi, 
beyazlara göre daha olasıdır (Horowitz ve Livingston, 2016). Anket sonuçları hareket ilişkin farkındalığı ortaya koyarken aynı zamanda harekete ilişin kafa karışıklığını da gözler önüne sermektedir. Amerikan siyasetinde uzun vadede etkin olup olamayacağı bu kafa karışıklığının giderilmesine bağlıdır.

Siyahların Hayatı Önemlidir protesto hareketinin beyaz ve (bazı) siyah yorumcular tarafından yapılan en yaygın eleștirilerinden biri, 1960'ların Sivil Haklar Hareketi'nin siyasi örnekliğini taklit edememesi olmuştur. Çağdaş BLM aktivistleri, daha önceki ırkçılık karşıtı mücadelelerin şiddet içermeyen mücadelelerine disiplinli bağlılık göstermedikleri, siyahların saygınlığını somutlaştırmadıkları, görünür bir hiyerarşik liderlik yapısı benimsemedikleri ve açık siyasal hedefler belirlemedikleri için eleştirilmektedir. Beyaz kamuoyunun, polis şiddetine karşı Siyahların Hayatı Önemlidir protestolarını tam anlamıyla söz konusu nedenlerden ötürü desteklemedikleri görülür (Hooker, 2016: 457). "Siyahların Hayatı Önemlidir", çoğu beyaz tarafından dışlayıcı bir çerçevede yorumlanır, sanki sadece siyahların hayatları önemlidir şeklinde değerlendirilir (Atkins, 2018: 1). Bu görüş ayrılıklarının BLM protestolarına ilişkin twitter etiketlerine de yansıdığı görülmektedir. Bazılarının "yasadışı ayaklanmalar" gördüğü yerde, diğerleri bu "haklı ayaklanmalara" katılmıștır (Hooker, 2016: 449).

Siyahların Hayatı Önemlidir hareketi, siyahların özgürlük mücadelesinde büyük öneme sahip olan Sivil Haklar Hareketi'nden birkaç yönden farklıdır. Birincisi, toplumsal hareketler üzerine çalışan Northeastern Üniversitesi Profesörü Sarah Jackson, Sivil Haklar Hareketi'nin insanları mitingler ve konuşmalar için harekete geçirmeye vurgu yapan ve karizmatik bir erkek lider etrafinda toplama eğiliminde olan "Martin Luther King-Al Sharpton modelini” benimsediğini düşünür. Ancak genç aktivistler, bunun yerine, Jackson'ın "Fannie Lou Hamer-Ella Baker modeli" olarak adlandırdığı - halkı kucaklayan ve eylemin tabana yayıldığı bir yaklaşımı- modeli öne çıkarıyorlar. Katılımcl demokrasiyi benimseyen BLM ünlülerin, özellikle Al Sharpton gibi karizmatik erkek liderliğini açıkça reddediyor (Tucker, 2018: 378). Liderliği tekil, karizmatik din adamı veya politikacı modelinden keskin bir şekilde ayrılıyor (Rickford, 2016: 34). BLM hareketinin kurucu aktivistleri, kökleri katılımcı demokrasi fikrini temel alan grup merkezli bir liderlik modelinde ısrarcıdırlar. BLM organizatörleri ayrıca hiç kimsenin veya bir grubun hareket adına konuşmaması veya kararlar almaması ilkesini benimserler (Harris, 2015). Daha az tanınan ama sivil haklar çağının son derece etkili bir stratejisti olan Baker, Martin Luther King'in Güney Hristiyan Liderlik Konferansı'nın kurulmasına yardım etmiş, ancak Martin Luther King'in çevresinde oluştuğunu hissettiği kişilik kültüne derin bir şüpheyle yaklaşmıştır. Hareket içindeki gücün, kilisede iktidar sahibi erkekler arasında birkaç liderde yoğunlaşması gerektiği fikrine açıkça karşı çıkmıştır. Güçlü insanların güçlü liderlere ihtiyaç duymayacağını vurgulamıştır (Demby, 2014). Aynı şekilde, BLM aktivistleri de bireylerin kendi eylemlerinin sorumluluğunu alması gerektiğini ve taban 
aktivizmini savunur (Tucker, 2018: 378). Bugün BLM aktivistleri, bir bireye veya bir avuç kişiye karar verme yetkisi vermenin hareketin devamlılığı için bir risk oluşturduğunu düşünmektedirler. Martin Luther King ve Malcolm X gibi karizmatik liderler güçlü çıkarlarla birlikte seçilebilir, kendi çıkarlarını kolektif çıkarların üstüne koyabilir, hükümet baskısıyla hedef alınabilir ve hatta suikasta uğrayabilir. Hareketlerin karizmatik liderlere bağımlılığı hareketleri zayıflatabilir veya etkisizleștirebilir (Harris, 2015). BLM güçlü tekil ve erkek egemen liderlik modeline şüpheyle yaklaşır. Aktivistlere göre, BLM hareketi içerisinde herkes birer lider ve karar vericidir. Bu bağlamda Siyahların Hayatı Önemlidir hareketi, karizmatik otoriteyi temel almayan ve her aktivistin birer lider olduğu "liderlerle dolu" bir hareket olarak değerlendirilebilir.

Kadın liderliği erkeklere göre arka planda kalan Sivil Haklar Hareketi'nin aksine, BLM üç kadın topluluk organizatörü Alicia Garza, Patrisse Cullors ve Opal Tometi tarafından kuruldu (Jones-Eversley vd., 2017: 315). Sivil Haklar Hareketi'nde erkekler liderlik rolünü üstlenirken, kadınlar ise toplumsal cinsiyet rollerinin öngördüğü şekilde organizasyon faaliyetlerine katılıyorlardı (Payne, 1990: 156). İkisi eşcinsel, biri Nijerya asıllı Amerikalı üç siyah kadının başlattığı bir hareket olan \#BlackLivesMatter ise yeni bir liderlik için siyasi alan açtı ve sonuç olarak yeni bir toplumsal hareket ortaya çlktı. Siyah trans bireyler, siyah eşcinseller, siyah göçmenler, siyah mahkûmlar ve sabıkalılar, siyah Y kuşağı, siyah kadınlar, düşük gelirli siyahlar ve engelli siyahlar bu hareketin merkezindedirler. Cesur, yenilikçi ve radikal bir liderlik modeli benimsenir (Tometi, 2015). Önceki hareketler, queer ve/veya kadınların katkılarını görmezden gelmiş veya asgariye indirmiştir. Özellikle de iki kurucusunun kendilerini hem queer hem de kadın olarak tanımladığı gerçeği göz önüne alındığında, BLM platformu kasıtlı olarak bu grupları kapsıyor (Clark vd., 2018: 156). BLM hareketi, daha önce sapkın olarak görülen topluluk üyelerini yükselterek (Clark vd., 2018: 148) açık bir şekilde kadınları, LGBTQIA+'ı ve diğer marjinalleşmiş siyahları merkeze alır (Clark vd., 2018: 150). BLM'ın kurucularından biri olan Alicia Garza'ya göre, BLM, siyahların polis veya siviller tarafından yargısız infaz edilmesinin ötesinde hedefleri olan bir harekettir. Bazı siyah topluluklarda var olan ve sadece siyahları siyahı sevmeye, siyah yaşamaya ve siyah satın almaya çağıran, toplumsal cinsiyet ile biyolojik cinsiyeti aynı olan erkekleri hareketin ön saflarında tutarken, engelli bireyleri ve LGBT'lileri göz ardı eden sığ bir milliyetçiliğin ötesine geçer. BLM, siyah queer ve trans bireylerin, engellilerin, kayıt dışı siyahların, sabıkalıların, kadınların ve cinsiyet spektrumundaki tüm siyahların yaşamlarını onaylar. Siyah kurtuluş hareketleri içinde marjinalleştirilmiş olanları merkez alır (Garza, 2014). Bu bağlamda BLM hareketi içerisinde diğer siyah özgürlük hareketlerinden farklı olarak erkek egemen dikey bir hiyerarşik yapı bulunmamaktadır. LGBT+ ve diğer marjinalleştirilmiş grupların ön planda olduğu görülebilir. Bugüne kadar sistem tarafından dışlanmış kesimlerin BLM hareketi içerisinde daha aktif olduğu anlaşılmaktadır. Bu husus Siyahların Hayatı Önemlidir hareketini 
diğer siyah özgürlük hareketlerinden ayırmaktadır. Yeni bir liderlik modeli ortaya koyulmaktadır. Bu model, bireyleri (erkekleri) ön plana çıkarmaz. Grup odaklı liderliği ve âdemi merkeziyetçi bir yapıyı benimser. BLM kendinden önceki siyah kurtuluş hareketlerinin devamı olarak görülebilecekse de ataerkil ve hiyerarşik bir yapılanmayı reddeder.

\section{Sonuç}

Michael Brown'ın öldürülmesiyle Missouri, Ferguson'da patlak veren gösterilerde protestocuların orantısız polis şiddetine maruz kaldığı Ağustos 2014'ten günümüze, ABD’de Afrikalı Amerikalılar açısından çok az şeyin değiştiği düşünülür. New York City'den Baltimore'a, St. Louis'e, Chicago'ya, Texas'a kadar silahsız siyahlar - erkekler, kadınlar ve çocuklar, eşcinseller, heteroseksüeller - çoğunlukla beyaz polisler tarafından öldürülüyor. Eric Garner'dan Akai Gurley'e Tamir Rice'a, Aiyana Stanley-Jones'a, Rekia Boyd'a, Sandra Bland'e, John Crawford'a ve Laquan MacDonald'a... Silahsız siyahların ölümlerinin öngörülebilir bir sonunun olmadığı (Hooker, 2016: 449) düşünülmektedir.

Bugün yeni bir toplumsal hareket (Rickford, 2016: 34) ve yeni Sivil Haklar Hareketi (Clayton, 2018: 449) olarak değerlendirilen BLM hareketi, 1960'ların sonu ve 1970’lerin başlarında ortaya çıkan Siyah Güç ("Black Power") hareketinden doğmuştur, Siyah Güç de 1950'lerin ve 1960'ların Sivil Haklar Hareketi'nden doğmuştur (Perry, 2016: 465). BLM, önceki siyah kurtuluş hareketlerinin ele aldığı bazı konuları ele alıyor: siyah insanlar suçlu olarak görülüyor ve siyah bedenler gözden çıkarılabilir olarak algılanıyor (Clayton, 2018: 449). BLM, siyahların kurtuluş mücadelesine önceki katkıları kabul edip takdir ederken, aynı zamanda taktiklerini ve görevlerini önceki hareketlerden farklılaştırarak başkalarının da bu mücadeleye katılması için yeni bir alan açıyor (Clark vd., 2018: 147). Kökeni kendinden önceki hareketlerle bağlantılı olsa da eşitlik arayışında kullanılan eylem tarzları ve organizasyon yapısı farklıdır. Önceleri siyahların hak ve özgürlük mücadelesinde geri planda kalmış veya hiç rol almamış grupları temsil etmeyi hedefleyen BLM, Sivil Haklar Hareketi'nin "bir sonraki dalgası” olarak düşünülebilir. Siyahların Hayatı Önemlidir hareketi siyahların hak ve özgürlükler mücadelesinde yeni bir sayfayı temsil etmeye adaydır. Diğer bir ifadeyle, Afrikalı Amerikalıların süregelen eşitlik mücadelesinin son halkası olarak değerlendirilebilecek olan BLM hareketi, Afrikalı-Amerikalıların bu mücadelesinde yeni ve farklı bir fasıl açma gayretindedir.

En az 400 yüzyıldır devam eden mücadelenin devamı ve son halkası olan (Dalton, 2015) Siyahların Hayatı Önemlidir ifadesi, bugün ABD’de yaygın bir söylem olarak kullanılmaktadır. Yeni bir toplumsal hareket olarak BLM sadece polis şiddetini odaklanmanın ötesinde siyahların ve "muteber" görülmeyenlerin yaşamlarını merkeze almayı hedeflemektedir. Çıkış noktası silahsız siyahların kolluk kuvvetleri veya siviller tarafından öldürülmesidir. Başlangıçta Amerikan geleneksel medyasında kendi seslerini duyuramayan BLM 
aktivistleri sosyal medya platformlarını yoğun olarak kullanmaktadır. Kamusal söylemleri "siyah dostu" haline getirmeye çalışmaktadırlar. Bir twitter etiketinden doğan hareket farklı bir liderlik, siyasal eylem tarzı ve organizasyon yapısına sahiptir. Katılımcı karar alma mekanizmasını, âdemi merkeziyetçi ve yatay bir örgütlenmeyi benimseyen BLM, geçmişteki siyah özgürlük hareketlerinde geri planda bırakılmış kesimleri hareketin merkezine alır. Ataerkil ve hiyerarşik bir yapılanmaya karşı çıkar ve taban örgütlenmesini benimser. BLM'ı sosyal medya platformları üzerinde oluşan birlikteliğin mekânda birliktelik yoluyla toplumsal harekete evrilmesinin bir örneği olarak değerlendirebilir. Sanal âlemde başlayan bu birlikteliğin ve duygudaşlığın Amerikan kamuoyunda karşılık bulduğu görülebilir.

Amerikan kamuoyunda belirli bir farkındalık oluşmasına katkıda bulunmasına karşın hala BLM'a ilişkin tereddütlerin olduğu değerlendirilmektedir. BLM'ın belirli başarılar elde etmesine karşın sistematik ve kalıcı bir değişime sebebiyet verip veremeyeceği tartışmalıdır. Toplumun farklı katmanlarına nüfuz ettiği düşünülen adaletsizliğin giderilebilmesinin uzun bir zaman alacağı düşünüldüğünde, BLM'ın uzun soluklu bir toplumsal hareket olarak varlığlnı koruyup koruyamayacağı belirsizdir. İleriye yönelik dönüşüm vizyonunun Amerikan kamuoyu tarafından kabullenilmesi ve benimsenmesi, sürdürülebilir toplumsal mücadele için elzemdir. Bu bağlamda BLM'ı değerlendirmenin henüz erken olduğu düşünülmektedir. BLM'ın Amerikan siyasetinde başarılı olup alamayacağı ve adalet ve eşitlik mücadelesinde ne gibi kazanımlar elde ede(meye)ceği ilerleyen dönemlerde değerlendirilmesi gereken bir husus olarak ayrı bir çalışmanın konusu olmaya adaydır.

\section{Kaynakça}

Atkins, A. (2018). Black Lives Matter or All Lives Matter? Color-blindness and Epistemic Injustice*. Social Epistemelogy, 33(4), 1-22.

Aymer, S. R. (2016). “I Can’t Breathe: A Case Study - Helping Black Men Cope With Race-Related Trauma Stemming From Police Killing and Brutality. Journal of Human Behavior In the Social Environment, 26(3-4), 367-376.

Carney, N. (2016). All Lives Matter; so Does the Race: Black Lives Matter and The Evolving Role of Social Media. Humanity \& Society, 40(2), 180-199.

Clark, A. D., Dantzler, P. A. \& Nickels, A. E. (2018). Black Lives Matter: (Re)Framing the Next Wave of Black Liberation. Research in Social Movements, Conflicts and Change, 42, 145-172.

Clayton, D. M. (2018). The Black Lives Matter and the Civil Rights Movement: A Comparative Analysis of Two Social Movements in the United States, Journal of Black Studies, 49(5), 448-480, DOI: 10.1177/0021934718764099.

Carrega, C. (2019). Judge tu Suggest Future for NYPD Cop Accused of Killing Eric Garner with Chokehold. ABC News, https://abcnews.go.com/US/judge-determine-future-nypd-cop-accused-killing-eric/story?id=63502832 [14.09.2021]. 
Cobb, J. (2016). The Matter of Black Lives, The New Yorker, https://www.newyorker. com/magazine/2016/03/14/where-is-black-lives-matter-headed [15.02.2021].

Cohen, J. L. (1985). Strategy or Identity: New Theoretical Paradigms and Contemporary Social Movements. Social Research, 52(4), 663-716.

Çopuroğlu, Y. C. \& Çetin, B. N. (2010). Yeni Sosyal Hareketler Paradigması Bağlamında Türkiye'deki Küreselleşme Karşıtı Grupların Birbirleriyle ve Dünyadaki Karşıtlarla Karşılaştırılması. Sosyoloji Araştırmaları Dergisi, 13(1), 67-100.

Dalton, D. (2015). The Three Women Behind the Black Lives Matter Movement. Madamenoire, https://madamenoire.com/528287/the-three-women-behind-the-black-lives-matter-movement/ [08.03.2021].

Day, E. (2015). Black Lives Matter: The Birth of a New Civil Rights Movement. The Guardian, https://www.theguardian.com/world/2015/jul/19/blacklivesmatter-birth-civil-rights-movement [15.02.2021].

De Choudhury, M., Shagun, J., Sugar B. \& Weber, I. (2016). Social Media Participation in an Activist Movement For Racial Equality. Paper presented at the 10th International AAAI Conference on Web and Social Media, Cologne, Germany, http://www. munmund.net/pubs/BLM_ICWSM16.pdf [12.03.2021].

Demby, G. (2014). The Birth of a New Civil Rights Movement. Politico Magazine, https://www.politico.com/magazine/story/2014/12/ferguson-new-civil-rights-movement-113906/ [10.03.2021].

Dessem, M. (2016). Watch the Black Lives Matter Speech Four NBA Stars Gave at the ESPY Awards. Slayt Magazine, http://www.slate.com/blogs/browbeat/2016/07/13/nba_stars_opened_the_espys_with_a_black_lives_matter_speech. html?via=gdpr-consent [16.02.2021].

Freelon, D., McIIwain, C. D. \& Clark, M. D. (2016). Beyond the Hashtags: \#Ferguson, \#Blacklivesmatter, and the Online Struggle for Offline Justice. Center For Media \& Social Impact, American University, Forthcoming, SSRN Electronic Journal, https:// papers.ssrn.com/sol3/papers.cfm?abstract_id=2747066 [04.03.2021].

Gafney, W. (2017). A Reflection on the Black Lives Matter Movement and its Impact on my Scholarship. Journal of Biblical Literature, 136(1), 204-207.

Gamson, W. A. (1968). Stable Unrepresentation in American Society. American Behavioral Scientist, 12(2), 15-21.

Garcia, J. Jee-Lyn \& Sharif, M. Z. (2015). Black Lives Matter: A Commentary on Racism and Public Health. American Journal of Public Health, 105(8), 27-30.

Garza, A. (2014). A Herstory of the \#BlackLivesMatterMovement by Alicia Garza. https://www.thefeministwire.com/2014/10/blacklivesmatter-2/ [07.01.2021].

Greene-Hayes, A. \& James, J. (2017). Cracking the Codes of Black Power Struggles: Hacking, Hacked, and Black Lives Matter. The Black Scholar, 47(3), 68-78.

Griffin, L. J. (2015). Skittles, AriZona Iced Tea, and Cigarettes: The Price of Black Lives in a "Post-Racial" America. The Assault on Communities of Color: Exploring the Realities of Raced-Based Violence (43-48), Kenneth Fasching-Varner \& Nicholas Daniel Hartlep (Ed.), Rowman \& Littlefield: Maryland.

Habermas, J. (1991). The Structural Transformation of the Public Sphere: An Inquiry into a Category of Bourgeois Society, MIT Press: Cambridge, MA. 
Heywood, A. (2013). Siyaset, (9. Baskı), Adres Yayınları: Ankara.

Harris, F. C. (2015). The Next Civil Rights Movement?. Dissent, https://www.dissentmagazine.org/article/black-lives-matter-new-civil-rights-movement-fredrick-harris [05.03.2021].

Hooker, J. (2016). Black Lives Matter and the Paradoxes of US Black Politics: From Democratic Sacrifice to Democratic Repair. Political Theory, 44(4), 448-469.

Horowitz, J. M. \& Livigston, G. (2016). How Americans View the Black Lives Matter Movement. Pew Research Center, FactTank: News in the Numbers, https://www.pewresearch.org/fact-tank/2016/07/08/how-americans-view-the-black-lives-matter-movement/ [04.03.2021].

Johnson, G. (2021). Officers Faces Charges in Restraint Death of a Black Man. AP News, https://apnews.com/article/george-floyd-7dbbc0146d17f4c26aeae1616d8d$66 \mathrm{cf}[17.09 .2021]$.

Jones-Eversley, S., Adedoyin, A. C., Robinson, M. A. \& Moore, S. E. (2017). Protesting Black Inequality: A Commentary on the Civil Rights Movement and Black Lives Matter. Journal of Community Practice, 25(3-4), 309-324.

Levenson, E. \& Chan, S. (2021). Grand Jury Indicts Police Officers and Paramedics in 2019 Death of Elijah McClain. CNN, https://edition.cnn.com/2021/09/01/us/elijah-mcclain-death-officers-charged/index.html [14.09.2021].

Lieberson, S. \& Silverman, A. (1965). The Precipitants and Underlying Conditions of Race Riots. American Sociological Review, 30(6), 887-898.

Linscott, C. "Chip" P. (2017). All Lives (Don't) Matter: The Internet Meets Afro-Pessimism and Black Optimism. Black Camera, 8(2), 104-119.

Lowery, W. (2017). Black Lives Matter: Birth of a Movement. Guardian, https://www. theguardian.com/us-news/2017/jan/17/black-lives-matter-birth-of-a-movement [11.03.2021].

Melucci, A. (1989). Nomads of The Present: Social Movements and Individual Needs in Contemporary Culture (Ed. John Keane \& Paul Mier), Radius: London.

Melucci, A. (1999). Çağdaş Hareketlerin Sembolik Meydan Okuması. Yeni Sosyal Hareketler: Teorik Açılımlar (Ed. Kenan Çayır), Kaknüs Yayınları: İstanbul.

Mundt, M., Ross K. \& Burnett, C. M. (2018). Scaling Social Movements through Social Media: The Case of Black Lives Matter. Social Media + Society, 4(4), 1-11.

Offe, C. (1999). Yeni Toplumsal Hareketler: Kurumsal Politikanın Sınırlarının Zorlanması. Yeni Sosyal Hareketler / Teorik Açılımlar, (Ed. Kenan Çayır), Kaknüs Yayınları: İstanbul.

Önder, T. (2008), "Yeşil Siyaset”, Siyaset, (Ed. Mümtaz'er Türköne), 591-628, Ankara: Lotus Yayınevi.

Parker, C. S. (2016). Does "Black Lives Matter" Still Matter?. The Conversation, https://theconversatioSilven.com/does-black-lives-matter-still-matter-62477 [04.03.2021].

Payne, Z. N. (1990). "Men Led But women Organized": Movement Participation of Women in the Mississippi Delta. Women and Social Protest (156-165), (Ed. Guida West \& Rhoda Lois Blumberg), Oxford University Press: Oxford \& New York. 
Perry, E. L. (2016). Teaching History in the Age of Black Lives Matter: Embracing the Narratives of the Long Struggle for Civil Rights. American Journalism, 33(4), 465470.

Peterson-Smith, K. (2015). Black Lives Matter: A New Movement Takes Shape. International Socialist Review, 96, https://isreview.org/issue/96/black-lives-matter, 17.02.2021.

Pichardo, N. A. (1997). New Social Movements: A Critical Review. Annual Review of Sociology, 23, 411-430.

Plohetski, T. (2020). 'I Can't Breathe!'Video Released from 2019 Death of Austin-area Black Man in Deputies' Custody. KVUE-ABC, https://www.kvue.com/article/news/ investigations/defenders/javier-ambler-death-investigation-williamson-county-sheriffs-live-pd/269-9065fe1e-bb16-439f-a008-fa74f741d5b4 [14.09.2021].

Reger, J. (2014). Debating US Contemporary Feminism. Sociology Compass, 8(1), 43-51.

Rickford, R. (2016). Black Lives Matter: Toward a Modern Practice of a Mass Struggle. New Labor Forum, 25(1), 34-42, DOI: 10.1177/1095796015620171.

Sidner, S. \& Simon, M. (2015). The Rise of Black Lives Matter: Trying to Break the Cycle of Violence and Silence. CNN, https://edition.cnn.com/2015/12/28/us/black-lives-matter-evolution/ [04.03.2021].

Singh, M. (2020). George Floyd Told Officers 'I Can't Breathe' More Than 20 Times, Transcript Shows. Guardian, https://www.theguardian.com/us-news/2020/ jul/08/george-floyd-police-killing-transcript-i-cant-breathe [14.09.2021].

Tatar, T. (2013). Yeni Toplumsal Hareketler ve Küresel Projeler. Ortadoğu Analiz, 5(57), 10-19.

Tucker, K. H. (2018). The Political is Personal, Expressive, Aesthetic, and Networked: Contemporary American Languages of the Self from Trump to Black Lives Matter. American Journal of Cultural Sociology, 6, 359-386.

Tometi, O. (2015). Celebrating MLK Day: Reclaiming Our Movement Legacy. Huffington Post, https://www.huffpost.com/entry/reclaiming-our-movement-l_b_6498400 [17.02.2021].

Topal Demiroğlu, E. (2014). Yeni Toplumsal Hareketler: Bir Literatür Taraması. Marmara Üniversitesi Sosyal Bilimler Dergisi, 2(1), 133-144.

Touraine, A. (2002). The Importance of Social Movements. Journal of Social, Cultural and Political Protest, 1(1), 89-95.

Walton, H. \& Smith, R. C. (2008). American Politics and the African American quest for universal freedom, (4th Ed), Pearson Longman: New York.

Weitzer, R. (2015). American Policing Under Fire: Misconduct and Reform. Society, 52(5), 475-480.

Williams, J. P. (2015). What does Black Lives Matter movement really want?. US News \& World Report, https://www.usnews.com/news/articles/2015/08/24/what-does-the-black-lives-matter-movement-really-want [22.02.2021]. 